\title{
Role of Amylin in Thyroid Cancer
}

\author{
Mona Mohamed Ibrahim Abdalla* \\ Physiology Department, Faculty of Medicine, MAHSA University, Malaysia
}

Submission: January 25, 2019; Published: February 28, 2019

*Corresponding author: Mona Mohamed Ibrahim Abdalla, Physiology Department, Faculty of Medicine, MAHSA University, Malaysia

\begin{abstract}
The prevalence of thyroid nodules and cancers were shown to be associated with type II diabetes mellitus (T2DM), obesity especially central obesity, and metabolic diseases. Recent studies reported that amylin, an amyloidogenic pancreatic peptide deposited in the pancreas in T2DM, theses aggregates enter the circulation and recently reported to be deposited in the brain and involved in the development of Alzheimer's disease. These circulatory amyloid aggregates may also deposit in the thyroid gland and causes activation of some pathogenic pathways that may result in the development of thyroid nodules and cancers. This review presents some of the available data about the role of amylin in type 2 diabetes mellitus (T2DM), the association between T2DM with thyroid carcinoma, and the possible role of amylin in the pathogenies of thyroid nodules and cancers.
\end{abstract}

Keywords: Cancer, Amylin, Insulin, Diabetes, Obesity, Neurodegenerative Diseases

\section{Introduction}

\section{Amylin and its Physiological Functions}

Amylin is a 37 -amino acid peptide that is co-secreted with insulin from $\beta$ cells of the pancreas in response to nutrients intake, such as glucose, amino acids and lipids [1]. It is also called as islet amyloid polypeptide (IAPP) as it is found in the form of myeloid aggregates in the pancreatic islets [2]. Amylin plays a role in glucose homeostasis, reducing blood glucose level, inhibiting food intake, an action that can be mediated by the effect of amylin on leptin expression and signalling in the ventromedial nucleus of the hypothalamus [3]. The effect of amylin on food intake can be also due to the central action of amylin on the area postrema as ablation of this area abolished the inhibitory effect of amylin on food intake [4]. Amylin decreases gastric motility and delay gastric emptying, an effect that helps in delaying the entry of nutrients into the small intestine, delaying intestinal absorption and subsequently decreasing the serum levels of different nutrients especially glucose. All those effects of amylin can explain athe effectiveness of using amylin agonists in the treatment of diabetes and the potential use of amylin obesity [5]. In addition to the centrally-mediated effect of amylin in delaying gastric empting and food intake, it has been also reported that amylin mRNA and its receptors are expressed in the stomach, suggesting a direct effect of amylin on gastric emptying [6].

Amylin is a member of the calcitonin family, which includes, $\alpha$ calcitonin-gene related peptides ( $\alpha$ CGRP), $\beta$ CGRP, adrenomedullin (AM) and intermedin (AM2). The effects of the calcitonin family members are mediated by calcitonin receptors (CTR) and CTR-like receptors (CLR). The specificity of those receptors for the members of calcitonin family depends on certain receptor-associated proteins called receptor-activitymodifying proteins (RAMPs) [7]. The receptors for amylin include, AMY1, AMY2, and AMY3, each consists of a combination of CTR with RAMP1, RAMP2, and RAMP3 respectively [8]. Amylin is metabolised via renal excretion and by proteolysis into less active and inactive metabolites [5]. Amylin (1-37) is the major molecular form of human amylin revealed by radioimmunoassay of the pancreatic tissue. There are two forms of circulating human amylin, the non-glycosylated form which is the biologically active form and the glycosylated form [9].

\section{Dysregulation of Amylin with Diabetes Mellitus}

Although amylin works to decrease blood glucose level, it is reported that amylin can be cytotoxic due to the formation of amylin aggregates; amyloids that associated conditions of T2DM [10]. Amylin aggregation in the pancreatic $\beta$ cells induces endoplasmic reticulum stress and damage of mitochondrial membrane resulting in death of the $\beta$ cells of the pancreas [8]. Normally, these aggregates once, formed, an autophagy process with be stimulated and degrade the aggregates protecting the cells from their cytotoxic effects as evidenced by the appearance of amyloids in the pancreatic $\beta$ cells of mice lacking ATG-7, ATG the autophagy-related proteins [11]. 


\section{Diabetes Mellitus and Thyroid Cancer}

Studies over decades confirmed the association of different types of cancer with diabetes especially T2DM. Worldwide, thyroid cancer is the most common endocrine malignancy among women [12]. The increasing prevalence of thyroid carcinoma as well as diabetes suggesting a link between them [13]. In 2017, Li et al. [14] published a met-analysis of 16 cohort studies that included 10,725,884 individuals, with a total of 8032 cases of thyroid cancer reported a positive association between the diabetes mellitus and increased risk of thyroid cancer mainly among women. In addition, a recent study reported a decrease in survival among patients with thyroid carcinoma who suffer from T2DM as compared with thyroid cancer patients who are not diabetics [13]. A more recent study reported an association between the increased risk of thyroid nodules with obesity, central obesity, insulin resistance and disturbed lipid profile [15]. Based on these studies, amylin may play a role in the pathogenesis of thyroid carcinoma. Understanding the regulation of amylin can help in enhancing its uses as a treatment or even as prophylactic.

\section{Conclusion}

Amylin is physiologically important in glucose homeostasis. However, if it forms aggregates, it causes cellular stress resulting in diseases such as diabetes mellitus. Increased association between T2DM with thyroid nodules and cancers suggests a possible role of amylin in the pathogenesis of thyroid carcinoma mediated by deposition of amyloids.

\section{References}

1. Qi D, Cai K, Wang O, Li Z, Chen J, et al. (2010) Fatty acids induce amylin expression and secretion by pancreatic beta-cells. Am J Physiol Endocrinol Metab 298(1): E99-E107.

2. Ogawa A, Harris V, McCorkle SK, Unger RH, Luskey KL (1990) Amylin secretion from the rat pancreas and its selective loss after streptozotocin treatment. J Clin Investig 85(3): 973-976.

3. Le Foll C, Johnson MD, Dunn-Meynell AA, Boyle CN, Lutz TA, et al (2015) Amylin-induced central IL-6 production enhances ventromedial hypothalamic leptin signaling. Diabetes 64(5): 1621-1631.

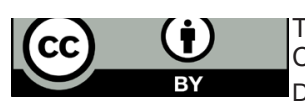

This work is licensed under Creative Commons Attribution 4.0 Licens DOI: $10.19080 / J E T R .2019 .04 .555631$
4. Lutz TA, Senn M, Althaus J, Del Prete E, Ehrensperger F, et al. (1998) Lesion of the area postrema/nucleus of the solitary tract (AP/NTS) attenuates the anorectic effects of amylin and calcitonin gene-related peptide (CGRP) in rats. Peptides 19(2): 309-317.

5. Bower RL, Hay DL (2016) Amylin structure-function relationships and receptor pharmacology: implications for amylin mimetic drug development. Br J Pharmacol 173(12): 1883-1898.

6. Friis-Hansen L, Wierup N, Rehfeld JF, Sundler F (2005) Reduced ghrelin, islet amyloid polypeptide, and peptide YY expression in the stomach of gastrin-cholecystokinin knockout mice. Endocrinology 146(10): 44644471.

7. Hay DL, Garelja ML, Poyner DR, Walker CS (2018) Update on the pharmacology of calcitonin/CGRP family of peptides: IUPHAR Review 25. Br J Pharmacol 175: 3-17.

8. Kiriyama Y, Nochi H (2018) Role and Cytotoxicity of Amylin and Protection of Pancreatic Islet $\beta$-Cells from Amylin Cytotoxicity. Cells $7(8):$ E95.

9. Fineman M, Koda J, Percy A, Rittenhouse J (1997) Glycosylated amylins.

10. Chiti F, Dobson CM (2017) Protein Misfolding, Amyloid Formation, and Human Disease: A Summary of Progress over the Last Decade. Annu Rev Biochem 86: 27-68.

11. Kim, J, Cheon H, Jeong YT, Quan W, Kim KH, et al. (2014) Amyloidogenic peptide oligomer accumulation in autophagy-deficient beta cells induces diabetes. J Clin Investig 124(8): 3311-3324.

12. Ron E, Schneider AB. Schottenfeld D, Fraumeni JFJr (2006) Thyroid cancer. Cancer Epidemiology and Prevention, Oxford University Press, New York pp. 975-994.

13. Jiang T, Qiao G, Zheng X, Wen Z, Zhang D (2017) Type 2 diabetes mellitus is more prevalent among patients with thyroid carcinoma and influences overall survival: a propensity scores matching analysis. Oncotarget 8(57): 97528-97536.

14. Li H, Qian J (2017) Association of diabetes mellitus with thyroid cancer risk: A meta-analysis of cohort studies. Medicine (Baltimore) 96(47): e8230.

15. Chen Y, Zhu C, Chen Y, Wang N, Li Q et al. (2018) The Association of Thyroid Nodules with Metabolic Status: A Cross-Sectional SPECT-China Study. Int J Endocrinol 6853617.

\section{Your next submission with Juniper Publishers} will reach you the below assets

- Quality Editorial service

- Swift Peer Review

- Reprints availability

- E-prints Service

- Manuscript Podcast for convenient understanding

- Global attainment for your research

- Manuscript accessibility in different formats

( Pdf, E-pub, Full Text, Audio)

- Unceasing customer service

Track the below URL for one-step submission https://juniperpublishers.com/online-submission.php 